\title{
Effective Customer Relationship Management: A Key to Success for Banks
}

\author{
${ }^{*}$ Mr. Gyanesh Bhatt \\ PhD Scholar, Faculty of Management, Jodhpur National University, Jodhpur, Rajasthan, (India)
}

\begin{abstract}
Generally, consumers do not change their banks unless serious problems occur. The philosophy, culture and organization of financial institutions were grounded in this assumption and reflected in their marketing policies, which were product and transaction-oriented, reactionary, focused on discrete rather than continuous activities.

With the advent of new technologies in the business of bank, such as Internet Banking and ATMs, now customers can freely choose any bank for their transactions. The pressures of competitive and dynamic markets have contributed to the growth of CRM in the Financial Services Sector. Also, before the Internet revolution, consumers largely selected their banks based on how convenient the location of bank's branches was to their homes or offices. With the advent of new technologies in the business of bank, such as Internet banking and ATMs, now customers can freely choose any bank for their transactions. Thus, the customer base of banks has increased, and so bas the choices of customers for selecting the banks.
\end{abstract}

Keywords: CRM, ATMs, Customer, Banks, Internet Banking

\section{Article Publication}

Published Online: 30-Jun-2021

\section{*Author's Correspondence}

8 Mr. Gyanesh Bhatt

8 PhD Scholar, Faculty of Management, Jodhpur National University, Jodhpur, Rajasthan, (India)

$\triangle$ bhattgyanesh541411@gmail.com

C 2021The Authors. Published by

International Journal of Management and Development Studies

This is an open access article under the

CC BY-NC-ND license

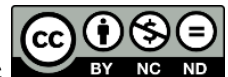

(https://creativecommons.org/licenses/b y-nc-nd/4.0/)

The Concept of Customer Relationship Management

Customer relationship management (CRM) is increasingly more important for businesses striving to grow in a challenging market. In addition to strengthening their competitive advantage today, business leaders must also prepare for potential opportunities in the future. Such pervasive insight requires integrated solutions that provide visibility across the entire business that can be easily accessed by an ever-growing number of internal stakeholders who rely on information to make more intelligent decisions. Too often, however, many companies still fail to take advantage of everything that effective CRM solutions have to offer. The results are limited business insight, failure to respond to ever-changing market conditions, and ultimately missed opportunities. Today, as CRM continues to evolve and organizations of all types and sizes increasingly take a more holistic approach to their CRM strategies, even greater emphasis must now be placed on future innovations in the CRM market. And that's a real challenge as IT professionals and business decision makers do their best to keep up with all of the constantly changing developments to ensure that they're getting the very most from their own CRM solutions.

Customer Relationship Management is the establishment, development, maintenance and optimization of long-term mutually valuable relationships between consumers and the organizations. Successful customer relationship management focuses on understanding the needs and desires of the customers and is achieved by placing these needs at the heart of the business by integrating them with the organization's strategy, people, technology and business processes. 


\section{Importance of CRM}

A Relationship-based Marketing approach has the following benefits: -

- Over time, retail bank customers tend to increase their holding of the other products from across the range of financial products / services available.

- Long-term customers are more likely to become a referral source.

- The longer a relationship continues, the better a bank can understand the customer and his/her needs \& preferences, and so greater the opportunity to tailor products and services and cross-sell the product / service range.

- Customers in long-term relationships are more comfortable with the service, the organization, methods and procedures. This helps reduce operating cost and costs arising out of customer error.

With increased number of banks, products and services and practically nil switching costs, customers are easily switching banks whenever they find better services and products. Banks are finding it tough to get new customers, and more importantly, retain existing customers.

According to a research by Reichheld and Sasser in the Harvard Business Review, 5\% increase in customer retention can increase profitability by $35 \%$ in banking business, $50 \%$ in insurance and brokerage, and $125 \%$ in the consumer credit card market. Therefore, banks are now stressing on retaining customers and increasing market share.

\section{Private Banking and CRM}

Private Banks have traditionally viewed themselves as exceedingly 'Customer Centric' offering what they believe to be highly personalized services to the High Net Worth Customers. However, changes in the customer behavior and accumulation of wealth are resulting in the needs of HNW customers becoming more diverse and complex in terms of the sorts of products they want, the channels through which they want to access them and the associated range of advice. The wealthier the customers, the more demanding they are and the clients expect more and more from their banks. Competition for "Supremely elite" is increasing

\section{Customer Experiences}

One must understand that the first step towards successfully winning, retaining and growing the profitability of private banking customers is to understand what their wants and needs are.

\section{The Basic Customer Experience}

There is a basic 'generic' customer experience that many private banking customers are seeking. To be a credible player in the market, a private bank must be able to deliver this 'base' experience. This represents a common set of needs that are shared by most High Net worth (HNW) customers. Therefore, the private bank must have the capabilities required to meet these needs for the majority of its customer base.

Take a simple example, HNW customers can afford on it to fund their retirement, so their priorities may be associated with growing wealth, rather than preserving it, allowing them to choose a product option with a higher risk/reward ratio.

If this is true, it means all HNW customers start with a basic, common set of what they want and need from a bank, which might include: - 
- Personal, long-term relationship

- Advice combining industry expertise and knowledge of personal circumstances

- High quality, consistent quality

- Security, privacy, confidentiality

At this basic level, grouping together these core wants and needs produces a set of generic characteristics that an HNW individual seeks from an organization before he or she will even consider placing any of his or her wealth with it.

\section{The Segment-Specific Experience}

To build this 'base' experience, private banks also need to consider the segment-specific needs of their target customers. This in itself requires a capability to identify and justify target customers and understand their needs beyond banking, to ensure that their emotional needs are met. It is here that the customer is made to feel like an individual, but it is also at this point that costs and infrastructure spiral, as customers' needs start to diverge.

The experience at this level is made up of: -

- The channel preferences of each segment and associated channel experience - for example, a selfdirected group of customers will use internet for transacting, information gathering and even some advice, whereas advice seekers and less financially sophisticated segments require more access to an adviser / relationship manager and a more basic experience over the Internet.

- The product and service preferences of that segment - for example, the more sophisticated customers are more likely to demand more complex products such as alternative investments, whilst others may prefer discretionary portfolio management.

\section{The Organisation-Specific Experience}

Having identified the base and segment specific elements of HNW customer experience, the final step is to identify how the experience that each organization offers its customers is distinct from other banks. Now this would mean that one has to distinctly identify the components of the experience that are not only associated with a particular bank but also be the key differentiator.

This process will define: -

- Elements of the organization style and culture.

- Products and Services to be provided.

- In the same way, every brand is different, so is the experience.

\section{Conclusion}

Frankly speaking, banking is mysterious for consumers and how they interact with their finances can be a complex matter. Technical solutions deployed by banks today are flexible, user-friendly and meant to facilitate specific workflow and requirements in implementation processes. In order to simplify lives, banks have begun to implement end-to-end technologies through all departments with the intention of removing human error from processes. 
Consumers largely selected their banks based on how convenient the location of bank's branches was to their homes or offices. $5 \%$ increase in customer retention can increase profitability by $35 \%$ in banking business, $50 \%$ in insurance and brokerage, and 125\% in the consumer credit card market. Therefore, banks are now stressing on retaining customers and increasing market share. Private Banks have traditionally viewed themselves as exceedingly 'Customer Centric' offering what they believe to be highly personalized services to the High Net Worth Customers. The wealthier the customers, the more demanding they are - and the clients expect more and more from their banks, to understand what their wants and needs are, so that the organization can be built around serving those needs. The structured approach to CRM provides various benefits to the bank, viz., a distinctive and consistent customer experience, clear identification of the organizational, technological and process-related capabilities and prioritization of these capabilities. The structure and hierarchy of the customer experiences are discussed in the paper. In Today's Era of E Banking and $\mathrm{E}$ Commerce customers enjoy complete luxury in terms of customized technical solutions and banks use the same to cement long-term, mutually-beneficial relationships with their customers and generate more customer base.

\section{References}

http://www.microsoft.com/dynamics/en/za/tapping-technology.aspx

http://searchcrm.techtarget.com/deflnition/CRM

http://en.wikipedia.org/wikUCustomer-relationship management.

http://nspl.co.in/CRM-Customer-Relation-Management-Software/CRM-History.html http://static.toodoc.com/download.php?s

CRM in banks -- Serve the customer Saumitra Bhaduri 'the author is Associate Professor, Madras School of Economics. Chennai.

http://www.buzzle.com/editorials/6-23-2006-100260.asp

Gartner, Inc. (6 June 2009) What's 'Hot' in CRM Applications in 2009

DestinationCRM.com (2012) What Is CRM?

James A. O'Brien \& George M. Marakas (2009). "Enterprise Business Systems, p.304". Management Information Systems. McGraw-Hill/Irwin..

James A. O'Brien \& George M. Marakas (2009). "Enterprise Business Systems, p.305". Management Information Systems. McGraw-Hill/Irwin..

Strativity Group, Inc. (2009) Global Customer Experience Management Benchmark Study

Inside CRM (2017) Get It Together with Collaborative CRM

DestinationCRM.com (2009) Who Owns the Social Customer?

Clara Shih, DestinationCRM.com (2009) Sales and Social Media: No One's social (Yet)

TechTarget (2009) Strategy Checklist: Planning for CRM and Customer Service Success

Lior Arussy (2015). "Understanding the Fatal Mistakes". Passionate and Profitable. John Wiley \& Sons, Inc.

"Avoid the Four Perils of CRM". Harvard Business Review. 